BALÁZS FEKETE*

\title{
Recent Trends in Extraterritorial Jurisdiction - The Sarbanes-Oxley Act and its Implications on Sovereignty
}

\begin{abstract}
This paper endeavors to analyze the current U.S. practice on the field of extraterritorial application of corporate governance law. As it is widely known, sovereignty is one of basic tenets of public international law, and its relevance is considerably debated in our age. Therefore, the main question of the paper is whether this qualitatively new U.S. practice on the field of extraterritoriality can contribute any insight for the better comprehension of the transformation of sovereignty. So, it will basically compare the lessons stemming from the adoption of the Sarbanes-Oxley Act to the classical concept of sovereignty.

In its first part the paper briefly introduces the reader into the basic notions of extraterritorial jurisdiction. In doing so, it analyzes some theoretical problems, the former U.S. antitrust law practice and the European approach. The second part of the paper deals with the SarbanesOxley Act as an emblematic and very actual example of corporate governance law having extraterritorial reach. This part discusses the major provisions of the act in detail as well as examines the different arguments justifying or criticizing it. In the last part the paper tries to reflect the results of the earlier inquires to different dimensions of sovereignty. Through three different prisms-Legislatio, Legitimatio and Subordinatio-the paper compares each aspect of sovereignty to the lessons flowing from the case of the Sarbanes-Oxley Act in order to get relevant insights concerning the transformation of sovereignty.

In conclusion, the paper argues that the classical 19th century approach of sovereignty is outdated because of the transformation of the global economic and political context. But, sovereignty, as a legal basis and legitimizing factor is still in play if the question is the protection of fundamental national interests. As it exactly happened in the case of the Sarbanes-Oxley Act which intends to protect a pillar-the confidence in corporate governance-of the basic structure of U.S. free market system.
\end{abstract}

Keywords: public international law, extraterritorial jurisdiction, Sarbanes-Oxley Act, sovereignty

Junior research fellow, Institute for Legal Studies of the Hungarian Academy of Sciences, H-1014 Budapest, Országház u. 30. Hungary, Lecturer, Pázmány Péter Catholic University, Budapest, Hungary.

E-mail: fbazsa@jak.ppke.hu. The manuscript was completed in October 2007.

The author is more than grateful to Professor Dr. Jan Wouters, Professor Dr. Marieke Wyckaert, Dr. Cedric Ryngaert and Ellen Lefever for their help and comments. 
"But it does suggest that current fashionable suggestions that State sovereignty is a thing of the past are to be understood with some cautions and perhaps some qualification"

Sir Robert Jennings

\section{Jurisdiction and extraterritoriality-A general introduction}

\section{Jurisdiction, from theoretical perspectives}

Law, since it is a human product, is necessary dependent upon time and circumstances. Its spatial, temporal and material boundaries are designated by the legislator itself and the practice of the community of states in the form of international customary law. The legislator can define the material, territorial, personal and temporal scope of a given legal rule, while international customary law regulates the collision of different states' legal spheres. Thus, the limits of a state's competences stem from both its own decision and the practice of the international community of states.

\subsection{The concept of jurisdiction}

The birth of the doctrine of jurisdiction is a necessary corollary of both the formation of the modern international political system and the emergence of modern state. ${ }^{1}$ The premise of states' sovereign equality, as a basic principle of the Westphalian system of international relations rendered necessary the elaboration of such rules of international law which are able to regulate the relationship among the colliding competences of states. If no state can subordinate other states to its will, since they are equal in a legal sense, international law regulating interstate relations needs such rules which can solve the conflicts in case of collision of legal rules of different states. Therefore, the emergence of the doctrine of jurisdiction was inevitable during the first centuries of legal modernity.

In the view of F. A. Mann, who elaborated a comprehensive theory of international jurisdiction, the concept of jurisdiction in international law consists of five constitutive elements. First of all, it is related to activities of a state, however it has nothing to do with the internal competences of state

${ }^{1}$ Cf. Weber, M.: Államszociológiai töredék [A Fragment of the Sociology of the State]. In: Takács P. (ed.): Államelmélet [State Theory]. Budapest, 2003. 48-70. 
organs based on municipal law. ${ }^{2}$ Secondly, jurisdiction is about a state's right to exercise certain of its powers. ${ }^{3}$ Thirdly, a state's right to exercise jurisdiction is exclusively determined by public international law. ${ }^{4}$ So, states cannot unilaterally determine the scope of their jurisdiction, it is delimited by public international law. Fourthly, jurisdiction is focused on states' right of regulation. ${ }^{5}$ Lastly, jurisdiction in international law has only relevance in those cases which are about matters not exclusively of domestic concern. ${ }^{6} \mathrm{He}$ concludes that jurisdiction "is concerned with what has been described as one of the fundamental functions of public international law, viz. the function of regulating and delimiting respective competences of States."

It is common ground in doctrine that jurisdiction comprised of the aforementioned five constituting components has three different aspects. One can use the expression of jurisdiction to elaborate on the opportunities of states how to perform acts in the territory of other states (executive jurisdiction), to explain the competences of courts to deal with cases in which a foreign factor is present (judicial jurisdiction), and to analyze the power of states to make binding laws to cases involving foreign elements (legislative jurisdiction). ${ }^{8}$

\subsection{The origins of the doctrine of jurisdiction, territoriality}

As a consequence of the predominance of the concept of sovereignty in the structure of modern international law a territorial approach of jurisdiction emerged during modernity. This territorial approach was in perfect conformity with the needs of modern international law which regarded the world as a community of sovereign states. All these sovereign states formed complete units of legal systems regulating legal relationships over their territory, as Bodin described it in his fundamental work. ${ }^{9}$

2 Mann, F. A.: The Doctrine of Jurisdiction in International Law. Recueil des Cours, 1964, I. 9.

3 Ibid. 9.

4 Ibid. 10.

5 Ibid. 13.

${ }^{6}$ Ibid. 15.

7 Ibid.

8 Shaw, M. N.: International Law. Cambridge, 2003. 576-578.; Akehurst, M.: Jurisdiction in International Law. British Yearbook of International Law 43 (1972-73) 177; Lowe, V.: Jurisdiction. In: Evans, M. (ed.): International Law. Oxford, 2003. 329.

9 Cf. Bodin, J.: Les six livres de la république. Paris, 1526. 
U. Huber in his work published in $1684^{10}$ laid down the foundations of the territorial theory of jurisdiction. In his axioms he announced that laws of sovereign authorities have only force within the boundaries of its state, and the exercise of sovereign authority should not prejudice that kind of power of other states. ${ }^{11}$ These axioms gradually became the guiding principles of the territorial conception of jurisdiction. Joseph Story only reformulated them in a more modern wording when he affirmed that "every nation possesses an exclusive sovereignty and jurisdiction within its own territory" and "no State can, by its laws, directly affect or bind property out of its own territory or bind persons not residents there" except so far as regards its own citizens. ${ }^{12}$ Story's general maxims were universally accepted in the community of international lawyers prior to World War I. Therefore, they dominated the doctori communis opinio about the scope of jurisdiction. ${ }^{13}$

However, the transformation of the structure of world economy, precisely both the strengthening of economic interdependence and the growing role of multinational enterprises, has been starting to progressively challenge this approach following the end of World War II. Due to the far-reaching consequences of the alteration of the world economic context the leading states of the world economy made severe attempts to regulate more-and-more that economic conduct which took place outside of their territories, but nevertheless affected their domestic market.

\subsection{Beyond the territorial principle and legislative jurisdiction}

This profoundly, or dramatically, altered economic environment induced the rethinking of the whole concept of jurisdiction which was born in a considerably different socio-economic context. Territoriality did not seem to be able to offer adequate answers for the novel problems of the post World War II era anymore. It became clear for the scholars' community that this traditional concept should be exceeded. It was also obvious that the whole paradigm needed rethinking, not only some parts of the territorial approach.

${ }^{10}$ The title of this work: De conflictu legum diversarum in diversis imperiis.

${ }^{11}$ Mann: op. cit. 26.

${ }^{12}$ Mann: op. cit. 28.

${ }^{13}$ However, in the Lotus-case, in 1927, the PCIJ argued that territoriality is not an absolute principle of international law and it does not coincide with territorial sovereignty. [PCIJ, Lotus case, No. 9. (France/Turkey), judgment of 7 September 1927, Permanent Court International Justice Report. Series A. Nr. 10, 20.] With this, the case-law opened the theoretical possibility to accept other approaches than strict territoriality. 
Mann suggested that international law concerning legislative jurisdiction should liberate itself from the chains of the traditional territorial approach and the time came for the elaboration of a qualitatively new approach. ${ }^{14}$ Therefore, he proposed a change of point of view at the beginning of the 60's. He suggested that international lawyers should not ask anymore whether certain facts can be subject to the legislation of a state, but whether the relevant facts of a case belong to a given jurisdiction. ${ }^{15}$ Therefore, in his view, problems of jurisdiction should be approached from the direction of the legislation, so from the aspect of a given state, rather than from the direction of the nature of the facts.

According to this approach, when deciding on jurisdiction, it must firstly be decided whether a given jurisdiction has a 'close connection' with the relevant facts of the case. The assessment of these facts from the aspect of territorial maxims may be of marginal importance. Hence, to claim jurisdiction over a given 'behavior' a close connection with the facts of the case is needed, not a territorial one. This close connection must demonstrate a genuine link, in other words a sufficiently strong interest in the case at hand. ${ }^{16}$ If a state's relation to a certain constellation of facts is "so close, so substantial, so direct, so weighty" ${ }^{\prime 17}$ then a state can legitimately, that is, in harmony with international law, claim the right of legislation in that respect.

In sum, Mann argues that mere political, social, economic or commercial interests cannot in themselves establish this close enough connection, since any declaration of jurisdiction should be in harmony with basic principles, such as non-interference, reciprocity, of international law. One may say that Mann proposed to reformulate the theory of jurisdiction on the basis of interest instead of the traditional territorial approach which looked to be quite oldfashioned within the conditions of an emerging global economy.

\subsection{The 'primary effects' approach}

As a further step in the inner development of the doctrine of jurisdiction Michael Akehurst suggested some additional refinement with regard to the effects doctrine forged out by the case law. In his view it implies certain obscurity from a theoretical point of view. As a main problem, Akehurst pointed out that the broad interpretation of this approach can easily refer to absolutely coincidental facts, remote and slight effects. And, asserting jurisdiction on this

\footnotetext{
${ }^{14}$ Mann: op. cit. 43.

${ }^{15}$ Ibid. 44-45.

${ }^{16}$ Ibid. 46.

${ }^{17}$ Ibid. 49.
} 
basis would have an unfavorable effect on trade relations. It is easy to accept that almost all transnational economic activities can have a certain effect on markets around the globe.

He proposed that the best way to avoid the implications related to a too broad interpretation, such as for instance too many states claiming jurisdiction in a given case, is to limit jurisdiction to that state where the primary effects of the business conduct occurred. In the determination of the primary or secondary nature of the 'effects' two factors should be taken into account. ${ }^{18}$ Firstly, are the effects more direct in a state than in other states? Secondly, are the effects occurring in a given state more substantial than in other states? On the basis of this 'primary effects test' it will be possible to differentiate among primary effects which may call for state intervention via its legislation and judiciary, and other effects which are too slight and remote to trigger the same mechanisms. In conclusion, as argued by Akehurst, this approach makes the exercise of jurisdiction possible by those states which have a legitimate interest in the given case. ${ }^{19}$ So, by this development, Mann's 'close connection' requirement is realized since this theory links the 'effects doctrine' with the legitimate interest of states. This approach helps to sufficiently sharpen the focus of the 'effects theory', so that it creates a reasonable framework for asserting jurisdiction over business practices occurring outside the territorial jurisdiction of a state.

\section{Globalized world economy and competition law}

The main goal of competition or antitrust law is to help the neutralization of those effects which can likely arise from an imperfect competition. Distortion of competition can have such outcomes which are unfavorable from the point of view of society. Monopolies cause welfare losses by maintaining prices above the optimal and blocking market entry for new innovative actors. Unfair or restrictive commercial practices also disturb the functioning of the market by depriving the consumer of information necessary to make optimal and wellfounded choices, that is, they cause informational asymmetries. Therefore market power and market actors are to be necessarily regulated in order to improve the work of the market. A smooth run of the market can increase the aggregated social welfare as followers of Adam Smith believe and teach it. ${ }^{20}$

${ }^{18}$ Akehurst: op. cit. 198.

${ }^{19}$ Ibid. 201.

${ }^{20}$ Cf. Van Cayseele, P. and Van den Bergh, R.: Antitrust Law. In: Bouckaert, E.Geest, G.: Encyclopedia of Law and Economics. http://encyclo.findlaw.com/5300book.pdf 
The birth of competition law at the end of $19^{\text {th }}$ century was thus an answer to regulate those circumstances which disturb the real functioning of the market. ${ }^{21}$ Of course, these early acts mainly intended to regulate the national market, that is, the domestic market of a given country. The structural features of the world economy prior to World War I and in the interwar period did not render it necessary to take into account foreign acts and facts to that degree as it is unavoidable today.

However, today's world economy is characterized by new features which separate it from the earlier stages. According to a historical approach, following the age of mainly land and agriculture based pre-industrial capitalism and the industrial, machine and finance based second phase of capitalism-in which the Sherman Act was born in 1890-a qualitatively new economic phenomenon has come forth in the last decades of the $20^{\text {th }}$ century.

This new form of capitalism is now mainly knowledge-based and has a global dimension in contrast to the limited spatial diffusion of the earlier stages. The distinctiveness of this new economic world order is based on five qualitatively new features. Firstly, cross-border transactions are deeper and more interconnected than they have ever been. Secondly, resources, goods and services are spatially more mobile than they have ever been. Thirdly, multinational enterprises play a more significant role in the creation and distribution of wealth than they have ever done before. Fourthly, the financial and real volatility has increased in a considerable degree due to the dramatically increased interdependence. And lastly, the advent of digital environment and electronic commerce has completely changed the character of cross-border transactions by making them much faster and easier. ${ }^{22}$

Therefore interdependence, ${ }^{23}$ which has transactional, spatial and informational dimensions in economic sense, ${ }^{24}$ is a keyword to understand that

\footnotetext{
${ }^{21}$ The first anti-trust acts were the following: the Sherman Act of 1890 (US), the Law against Unfair Competition (Gesetz gegen den unlauteren Wettbewerb) of 1909 (Germany), the Clayton Act of 1914 (US), and the Combines Investigation Act of 1923 (Canada).

${ }^{22}$ Dunning, J. H.: Global Capitalism at Bay. London, 2001. 13.

${ }^{23}$ A guiding indicator of economic globalization in the sense of interdependence is the trade-to-GDP ratio (in other terms the "trade openness ratio"). Between 1992 and 2005 this indicator increased by 13 percentage points for the whole OECD. For the details see http://titania.sourceoecd.org/pdf//fact2007pdf//03-01-01.pdf. And Cf. Woods, N.: The Political Economy of Globalization. In: Woods, N. (ed.): The Political Economy of Globalization. London, 2000. 1-3.

${ }^{24}$ For a detailed and broader discussion of interdependence in international law see: Wouters, J.: Perspectives for International Law in the Twenty-First Century: Chaos or World Legal Order. Ethical Perspectives 7 (2000) 17-23.
} 
economic context in which the problems of extraterritoriality in antitrust cases have arisen in the last decades.

\section{Extraterritoriality in antitrust cases; general introduction}

The very first problems of extraterritoriality in antitrust cases have already appeared in the first decade of the $20^{\text {th }}$ century and they continuously crystallized during the whole century. So, anti-trust extraterritoriality has a history of more than ninety years. The experiences of this period may help to formulate some general premises supporting the particular research of the new trends in the second part.

\subsection{The genesis of the U.S. practice}

Thus, in accordance with the classical doctrine of public international law, legislative jurisdiction regarding restrictive business practices is subject to those limitations which stem from territoriality. ${ }^{25}$ However, within the conditions of a highly interrelated world economy characterized by several dimensions of interdependence it is more-and-more difficult to localize such business practices which extend beyond a certain scale. ${ }^{26}$ Generally, business transactions beyond and over national boundaries can be realized in a form of complicated patterns of conduct implying a longer time period and a transnational, even global spatial area. ${ }^{27}$ So, these practices necessary have a transnational character due to the very nature of their economic context, and this transnational nature encodes some problems of extraterritoriality from the point of view of legislator.

\subsubsection{The prior-Alcoa period, the first antecedents}

U.S. antitrust law is fundamentally based on two legislative acts; on the Sherman Act of 1894 and Clayton Act of 1914. While the Sherman Act in its first paragraph declared that all anticompetitive business illegal, ${ }^{28}$ so to say it

${ }^{25}$ For an analysis of alternative legal bases for the application of antitrust law see: Basedow, J.: International Antitrust: From Extraterritorial Application to Harmonization. Louisiana Law Review 61 (1999-2000) 1039-1042.

${ }^{26}$ On the question of localization see Mann: op. cit. 36-37.

${ }^{27}$ Ibid.

${ }^{28}$ Sherman Act $1 \S$ "every contract, combination in the form of a trust or otherwise, or conspiracy, in restraint of trade or commerce among the several States, or with foreign nation, is declared to be illegal." Stranger, A.: Analyzing U.S. Antitrust Jurisdiction over foreign parties after Empagran S.A. v. F. Hoffman-LaRoche, Ltd. Brigham Young University Law Review, 2003. 1456. 
indicated the general U.S. antitrust attitude, the Clayton Act established a detailed procedural framework for antitrust affairs. ${ }^{29}$ Additionally, the legislator announced that their provisions equally apply for domestic and foreign business practices by explicitly addressing activities among foreign nations. ${ }^{30}$

Nevertheless, from the birth of the Sherman Act to the first decade of the $20^{\text {th }}$ century, U.S. courts did not think of applying the Sherman Act for business practices occurring outside U.S. territory. ${ }^{31}$ Justice Oliver Wendell Holmes, as a judge of the U.S. Supreme Court, in his opinion in the American Banana v. United Fruit $\mathrm{Co}^{32}$ pointed out that the lawfulness of an act causing damage in the U.S. "must be determined wholly by the law of the country where the act is done". ${ }^{33}$

However, this practice based on a restrictive interpretation of the Sherman Act radically changed by the judgment in the case of United States v. Am. Tobacco Co ${ }^{34}$ in 1911. The court held that an agreement between a U.S. and a British tobacco syndicate is under the scope of U.S. antitrust law notwithstanding that the agreement was concluded under British jurisdiction. ${ }^{35}$ Moreover, Chief Justice White argued that a specific "rule of reason" imposes U.S. antitrust law to foreign cartels if they significantly threaten U.S. commerce. ${ }^{36}$ With this judgment the case-law ${ }^{37}$ confirmed the legislator's intent concerning the extraterritorial scope of the Sherman Act.

${ }^{29}$ The Clayton Act concerning the enforcement of antitrust law provided that the U.S. government can bring both civil and criminal suits in case of an illegal, anti-competitive conduct. Moreover, it mandated private parties to bring suits, and provided treble damages for successful complaints. Ibid. 1457.

${ }^{30}$ Ibid. 1458.

${ }^{31}$ The U.S. Supreme clearly declared in Rose v. Himely [8 U.S. (Cranch) 241 (1806)] that, on the basis of conflict-of-laws rules, U.S. legislation is basically territorial, and beyond its borders it can only affect its subjects and citizens. Moreover, in 1812, it forged out a presumption that federal law applies only within the U.S. Norton, J. J.: Extraterritorial Jurisdiction of U.S. Antitrust and Security Laws. The International \& Comparative Law Quarterly 28 (1979) 577.

32213 U.S. 347 (1909).

${ }^{33}$ Mehra, S. K.: Extraterritorial Antitrust Enforcement and the Myth of International Consensus. Duke Journal of Comparative \& International Law, 1999. 204,; Falencki, C. A.: Sarbanes-Oxley: Ignoring the Presumption Against Extraterritorialty. The George Washington International Law Review 35 (2004) 1219.

${ }^{34} 221$ U.S. 106 (1911).

${ }^{35}$ Stranger: op. cit. 1458 , footnote 24.

${ }^{36}$ Ibid. Footnote 25.

${ }^{37}$ Other cases disregarding the principle of territoriality in antitrust matters: Strassheim v. Daily [221 U.S. 280 (1911)], U.S. v. Pacific \& Arctic Co. [228 U.S. 87 (1913)], and U.S. 


\subsubsection{The "effects doctrine" and the Alcoa judgment}

As we have seen in the prior World War II period, the U.S. courts, following some hesitation, consequently applied U.S. antitrust law to anticompetitive foreign business practices affecting the domestic market. However, it should also be recognized that they did so on the basis of occasional considerations, so they did not forge out a coherent doctrine for the justification of their practice.

The so-called "effects doctrine" was born in the famous Alcoa decision of the Second Circuit. Since it was able to offer a solid conceptual framework for antitrust litigation having extraterritorial dimensions, it could swiftly replace the earlier fragmented practice. In 1945 in the US v. Aluminium Company of America and others ${ }^{38}$ (the Alcoa case) the court had to decide on such economic effects which resulted from business practices of foreigners outside of the USA. In the given case an agreement among foreign aluminium producing companies affected aluminium imports to the United States. ${ }^{39}$ The Court argued that "It is a settled law [...] that any State may impose liabilities [...] for conduct outside its borders that has consequences within its borders." 40 Furthermore, the Court also asserted that the intention to produce effects on the territory of United States is sufficient to invoke the jurisdiction of the US. And, if this intention is proved, the burden of proof will automatically shift to the defendant to prove that his acts have no such effects. ${ }^{41}$

The details of the effects doctrine were elaborated by Judge Learned Hand's opinion in this case. According to him four conditions must be fulfilled to assert US laws over those conducts which occurred outside the territory of US. First of all, a close connection between the conduct and its effect is necessary. Secondly, this effect must be substantial, so it cannot have marginal relevance concerning the given market segment. Thirdly, the effects must be "direct and foreseeable"; a mere coincidence of facts is not enough to assert jurisdiction. Fourthly, the application of this doctrine should be "consistent with generally recognized principles of justice". ${ }^{42}$

v. Sisal [274 U.S. 268 (1927)]. Common in these cases that the Court chose quite diverse legal bases for the justification of its extraterritorial jurisdiction, for example: producing detrimental effects, the realization of the conspiracy happened partially in the U.S., or the intention of the parties. Norton: op. cit. 577-579.

${ }^{38} 148$ F. 2d 416 (2nd Cir. 1945).

39 Akehurst: op. cit. 193.

${ }^{40}$ Quoted by Akehurst, ibid.

${ }^{41}$ Ibid. 194.

${ }^{42}$ De Kieffer, D. E.: Effects on US Trade. In: Lacey, J. R. (ed.): Act of State and Extraterritorial Reach: Problems of Law and Policy. New Orleans, 1982. 63. 
3.1.3. Post-Alcoa developments: the Timberlane decision and the FTAIA

Following the Alcoa-judgment the 'effects theory' was applied in many US antitrust cases. ${ }^{43}$ In 1976 the Ninth Circuit in Timberlane Lumber Co. v. Bank of America ${ }^{44}$ substantially improved this approach by amending the traditional effects test with the element of comity. ${ }^{45}$ In the view of the Ninth Circuit the "effects test" simply failed to take into account other states' legitimate interests. A so-called "jurisdictional rule of reason" $"$ should be applied in addition to the effects analysis in order to decide whether a U.S. Court has jurisdiction over a certain business activity. This "jurisdictional rule of reason" is composed of several factors which should be assessed to assert jurisdiction. Chief amongst these factors are: (i) the degree of conflict with foreign law or policy, (ii) the extent to which enforcement by either state can be expected to comply, (iii) the extent to which there is an explicit purpose to harm or affect American commerce, and (iv) the relative importance of the given conduct within the U.S. as compared with conduct abroad. ${ }^{47}$ So, by adding the element of comity to the "effects test" the Ninth Circuit considerably blunted its edge and therefore it contributed to the consolidation of the quite upheaval international atmosphere. $^{48}$

The Free Trade and Antitrust Improvement Act of 1982 (FTAIA) could also be regarded as a qualitatively new development in the story of "effects test". This procedural statute amending the Sherman Act attempted to unify those divergent "effects tests" which were elaborated in the judgments of different courts. ${ }^{49}$ The FTAIA requires the Sherman Act to apply to all conduct related to imports, and it can also be applied in those cases where there is a direct, substantial and reasonably foreseeable effect on U.S. commerce or U.S. exports and this effect "gives rise to a claim under the Sherman Act". 50

${ }^{43}$ The US courts referred to this doctrine in US v. Timken Roller Bearing Co. [83 F. Supp. 284 (1951)], US v. General Electric Co. [82 F. Supp. 753 (1953)], US. v. The Watchmakers of Switzerland Information Centre [Trade Cases 77, 414. (1963)] and Hazeltine Research, Inc. v. Zenith Radio Corp. [239 F. Supp 51, 78 (1969)]. Cf. Akehurst: op. cit. 194.

44549 F. $2 d 597$ ( $9^{\text {th }}$ Cir. 1976)

${ }^{45}$ About the concept of comity and its role in antitrust litigation see Mehra: op. cit. 203-211.

${ }^{46}$ Ibid. 205.

${ }^{47}$ Quoted by Mehra, ibid.

${ }^{48}$ For critics of this approach on the basis that assessing the interests of states is not part of the judicial function see: Durack, P.: Australia: Conflicts and Comity. In: Act of State and Extraterritorial Reach... op. cit. 48-49.

${ }^{49}$ Cf. Stranger: op. cit. 1459-1460.

${ }^{50}$ Ibid. 1461. 
However, the FTAIA was not as successful as initially hoped by the legislator. Because of the ambiguous expression of "gives rise to a claim" divergent interpretations began to develop around the question who precisely can have standing before a U.S. court in an antitrust case. In case if the plaintiff is a U.S. company no problems arise since it can raise the claim without difficulties. ${ }^{51}$ Conversely, if the given case is about damages occurring outside the U.S. market, which may affect the U.S. market, as a result of non-U.S. companies' act, the interpretation of the "gives rise to a claim" clause is more problematic. U.S. courts tried to solve this question in three different and divergent ways. The Fifth Circuit held in Den Norske Stats Oljeselskap As v. HerreMac Vof ${ }^{2}$ case that this clause only allows for plaintiffs who are injured in connection with the effect, so it interpreted it very narrowly. ${ }^{53}$ The Second Circuit in Kruman v. Christie's International ${ }^{54}$ chose a different approach by declaring that on the basis of this clause it is possible to grant jurisdiction if the plaintiff can show evidence of a hypothetical claim under U.S. laws. ${ }^{55}$ Finally, the D.C. Circuit also created its own interpretation. As it was elaborated in Empagran S.A. v. Hoffman-LaRoche, $L t d^{56}$ foreign plaintiffs can have standing if they bring a suit alongside those U.S. plaintiffs who had suffered damages in the U.S. ${ }^{57}$

\subsection{The European approach}

The European Union and the EU member states, on a political and a legislative level, produced quite a hostile reaction regarding the extraterritorial reach of U.S. antitrust law. The United Kingdom, as for instance, adopted the U.K. Protection Trading Interests Act in 1980 in order to outweigh the negative consequences flowing from the U.S. practice. Moreover, in the 90's the EU in many press releases questioned the legality of the extraterritorial application of the Helms-Burton ${ }^{58}$ and D'Amato ${ }^{59}$ acts and other laws ${ }^{60}$ which established

${ }^{51}$ Ibid. 1464.

${ }^{52} 241$ F. 3d 420 ( $5^{\text {th }}$ Cir. 2001).

${ }^{53}$ For details see: Stranger: op. cit. $1465-1466$.

${ }^{54} 284$ F. 3d 384 (2 $2^{\text {nd }}$ Cir. 2002).

${ }^{55}$ For details see: Stranger: op. cit. $1466-1468$.

${ }^{56} 315$ F. 3d 338 (D.C. Cir. 2003).

${ }^{57}$ Stranger: op. cit. 1470.

${ }^{58}$ Cuban Liberty and Democratic Solidarity Act of 1996.; for a detailed discussion of the act from the point of view of the entertprises see: Wallace, C. D.: The Multinational Enterprise and Legal Control. The Hague-London-New York, 2002. 613-625.

${ }^{59}$ Iran and Lybia Sanctions Act of 1996. 
unilateral sanctions against the so-called "rouge" states between 1993 and 1996. Obviously these acts considerably affected other nations' trade and commerce by unilaterally blocking commerce and business participation in the sanctioned countries. The result of long-lasting negotiations was a Transatlantic Cooperation Agreement in 1998. Thereby the U.S. government provided a waiver under these acts for the European Union in exchange for suspending the WTO proceedings against these acts initiated by the European Communities. ${ }^{61}$

From the earlier it may seem that the EU and its member states have been quite reluctant towards the extraterritorial application of laws, and they have approached this problem from the direction of solid territoriality. However, the analysis of some ECJ and Commission decisions may suggest a slightly shaded conclusion. During the 60's and 70's the Commission and the Court of Justice have already applied the effects doctrine to claim jurisdiction over certain business conducts. In cases related to distributorship agreements, Martens and Streat v. Bendix (1964) and Béguelin Import Co. v. S.A.G.L. Import Export $(1971)^{62}$ or market-access agreements, Grossfillex v. Fillistorff (1964), the European Commission or the ECJ partially applied "effects doctrine". ${ }^{63}$

It is also very intriguing that the Advocate Generals in Imperial Chem. Indus. v. Commission ${ }^{64}$ and Ahlström v. Commission ${ }^{65}$ explicitly referred to the "effects test" by using the same criteria-substantial, direct and foreseeable-as used in the U.S. ${ }^{66}$ But, the ECJ by applying different legal constructions avoided the explicit application of the "effect test" in order to establish its jurisdiction. Finally, in 1999 in Gencor v. Commission ${ }^{67}$ the ECJ declared that it has jurisdiction if the conduct, in this case a merger, can have an immediate and substantial effect on the EC market. In this case the ECJ acknowledged that the application of the "effects test" is not contrary to international law. ${ }^{68}$ Thus, while on a political level the countries of the EU and the EU in itself has

\footnotetext{
${ }^{60}$ Between 1993 and 199661 laws and other administrative actions were adopted, which authorized unilateral economic sanctions against 35 countries. For a detailed list see: Layton, A.-Parry, A. M.: Extraterritorial Jurisdiction: European Responses. Huston Journal of International Law, 30 (2004) 315; footnote 22.

${ }^{61}$ For a detailed discussion of the whole process see ibid. 315-318.

${ }^{62}$ Case C-22/71 Béguelin Import v G.L. Import Export (Rec. 1971, 949).

${ }^{63}$ Akehurst: op. cit. 197.

${ }^{64}$ Case C-48/69 Imperial Chem. Indus. v Commission [1972] European Court Reports, 619.

${ }^{65}$ Case C-89/85 Ahlström v Commission [1988] European Court Reports, 5193.

${ }^{66}$ Layton-Parry: op. cit. 318-320.

${ }^{67}$ Case T-102/96 Gencor Ltd. v Commission [1999] European Court Reports, II-753.

${ }^{68}$ Layton-Parry: op. cit. 322.
} 
a quite conservative standpoint concerning the extraterritorial application of U.S. laws, the practice of the ECJ seems to be quite similar to the U.S. practice.

\section{Recent developments on the field of corporate governance law}

\section{Changing scope: from behavior of market actors to their governance techniques}

Following the earlier brief theoretical-historical overview the paper wishes to turn to recent tendencies. As a starting point of this analysis it might be worthwhile recognizing a qualitatively new trend underlying the development of extraterritorial jurisdiction issues. As we have seen in the first part, from the 50 's to the 80's the problems of extraterritoriality mostly flowed from such conducts of economic actors which may affect the domestic market. However, following the adoption of Sarbanes-Oxley Act in $2003^{69}$ the focus of questions concerning extraterritoriality suddenly shifted to the area of corporate governance. So, while in the first four decades of the history of extraterritorial jurisdiction problems were mainly arising from the conduct of economic actors, their restrictive practices which may affect the domestic market, nowadays the main problem of legislation having extraterritorial reach is how these economic operators direct their businesses. So, the whole problem of extraterritoriality got a relatively new layer in the last years besides the 'traditional' issue of transnational restrictive economic practices. ${ }^{70}$

\footnotetext{
${ }^{69}$ For the full text of the act see http://www.sec.gov/about/laws/soa2002.pdf

${ }^{70}$ Although commentators agree that U.S. securities laws, in principle, cannot be extraterritorially applied there are some very limited exceptions under this rule. In. Schoenbaum v. Firstbrook (403 f. 2d 200 ( $2^{\text {nd }}$ Cir. 1967) and in Leasco Data Processing Equipment Corp. v. Maxwell (468 F. 2d 1326 ( $2^{\text {nd }}$ Cir. 1972) the Second Circuit found that sec. 10 (b) (an anti-fraud provision) of the Securities Exchange Act of 1934 can be extraterritorially applied. And, the court developed a specific conflict-of-laws rule for the extraterritorial application of this section of the act in Bersch v. Drexel Firestone (549 F. 2d 614 ( $9^{\text {th }}$ Cir. 1976). For details see Norton, J. J.: op. cit. 584-587 and 590-591. Additionally, the judgment in Consolidated Goldfields plc. V. Minorco S.A. (871 F. 2d 252 (1989) also raised the certain questions about the extraterritoriality of U.S. securities laws. Cf. F. A. Mann: The Extremism of American Extraterritorial Jurisdiction. The International and Comparative Law Quarterly 39 (1990) 410-412. Furthermore, this development has also some antecedents in certain provisions of the Foreign Corrupt Practices Act of 1977. This act covered conduct of (i) U.S. companies' subsidiaries abroad as well as (ii) foreign
} 


\section{The Sarbanes-Oxley Act and its extraterritorial implications}

The Sarbanes-Oxley Act enacted on July 30, 2002 has opened a new chapter in the history of extraterritoriality. According to U.S. commentators it should be regarded as the most comprehensive corporate reform legislation since the reforms that had been introduced under the presidency of Franklin Delano Roosevelt. ${ }^{71}$ Both the Securities Act of 1932 and the Securities Exchange Act of 1934 mainly intended to give concrete answers to the financial crisis of 1929 from the aspect of corporate and securities affairs. Commentators also agree that the decisive impetus behind the provisions of the Sarbanes-Oxley Act were the corporate scandals between 2001 and 2002 coined by such companies' names as Enron, World Com Inc., Adelphia Communications Co. and so on. ${ }^{72}$ Thus, the Sarbanes-Oxley Act must be regarded as a clear governmental answer to certain failures and shortcomings of the U.S. corporate system and one of its major aims is to restore and preserve investors' confidence in the securities market. ${ }^{73}$

It is more than a commonplace that the U.S. securities market is one of the world's most important marketplaces. ${ }^{74}$ Foreign companies are traditionally actors on these capital markets, therefore extraterritorial problems were implied from the very first moment of the birth of the act.

companies registered under the Exchange Act. De Kieffer: op. cit. 61-62. But corporate governance issues from the aspect of extraterritoriality were impressively and comprehensively raised by the Sarbanes-Oxley Act.

${ }^{71}$ Lunt, M. G.: The Extraterritorial Effects of the Sarbanes-Oxley Act 2002. Journal of Business Law, 2006. 250. President Bush regarded it as "the most far-reaching reforms of American business practices" Thompson, J.: The Paradoxical Nature of the SarbanesOxley Act as it Relates to the Practitioner Representing a Multinational Corporation. Journal of Transnational Law and Policy 16 (2006) 266.

${ }^{72}$ Lunt: op. cit. 249.; On the background and the legislative history of the SarbanesOxley Act see Falencki: op. cit. 1212-1214.

${ }^{73}$ In the words of William Donaldson, former president of the Securities and Exchange Commission. Quoted by Stoltenberg, C.-Lacey, K. A.-George, B. C.-Cuthbert, M.: A Comparative Analysis of Post-Sarbanes-Oxley Corporate Governance Developments in the U.S. and European Union. The American Journal of Comparative Law 53 (2005) 462.; Or, in the words of Congress, as it was formulated in the act's preamble, the aim of the act is "To protect investors by improving the accuracy and reliability of corporate disclosures made pursuant to the securities laws, and for other purposes."

${ }^{74}$ Most of the major transnational companies are registered companies on the U.S. securities exchanges. Cf.: http://www.sec.gov/divisions/corpfin/internatl/foreignsummary 2006.pdf 


\subsection{Nexus to extraterritoriality}

Concerning the extraterritorial scope of the Sarbanes-Oxley Act, its definition of "issuer" has a predominant importance. In its $2 \S$ (a) (1) the act defines "issuer" as

"an issuer (as defined in section 3 of the Securities Exchange Act of 1934), the securities of which are registered under section 12 of that Act, or that is required to file reports under section 15 (d), or that files or has filed a registration statement that has not yet become effective under the Securities Act of 1933, and that is has not withdrawn.,"75

Thus, the decisive factor from the personal scope of the act is either the fact that a company's securities are registered according to the Securities Exchange Act or the company is required to send reports to the Securities and Exchange Commission (SEC). Therefore, all non-U.S. companies registered on the US. securities exchanges and reporting with the SEC are under the scope of the act. $^{76}$ So, all companies whose securities are traded in the U.S. must comply with the provisions of the Sarbanes-Oxley Act. Therefore, it is clear that the act has an extraterritorial scope from the point of view of those multinational enterprises that are registered on U.S. securities exchanges.

\subsection{The major provisions of the act}

The Sarbanes-Oxley Act introduced numerous new provisions concerning the traditional corporate governance structure of U.S. companies. These provisions specifically aimed to strengthen the transparency of the companies' affairs so they are answers to a specific problem of the U.S. corporate governance model. However, they may be in conflict with foreign corporate governance laws due to the explicit extraterritorial nature of the act arising from its definition of "issuer". Thus it is inevitable to get to know them better, in order to understand the vehement foreign, mostly European, reactions.

The act introduced reform in the following areas of corporate governance. ${ }^{77}$ Firstly, it instituted certain reforms regarding the pre-Enron corporate struc-

\footnotetext{
${ }^{75}$ Quoted by Falencki: op. cit. 1222.

${ }^{76}$ On December 31, 20061145 foreign companies were registered. Cf.: http://www. sec.gov/divisions/corpfin/internatl/foreignsummary2006.pdf

${ }^{77}$ On the basis of M. D. Vancea's categorization, however by restructuring it and amending it with new elements Cf. Vancea, M. D.: Exporting U.S. Corporate Governance Standards through the Sarbanes-Oxley Act: Unilateralism or Cooperation. Duke Law Journal 53 (2003) 838-839.
} 
tures of U.S. companies by (i) establishing the so-called audit committee, as a compulsory requirement for all companies under its scope $;^{78}$ (ii) expanding certain disclosure requirements for principal executive officers $;{ }^{79}$ (iii) introducing new certification requirements for CEOs and CFOs $;{ }^{80}$ (iv) prohibiting loans to executives of a company ${ }^{81}$ and (v) establishing an efficient "whistleblower protection" system for employees providing information about the financial situation of a company. ${ }^{82}$ Secondly, it made serious efforts in order to (vi) considerably enhance the independence of auditors by dramatically decreasing the potential personal and business relationship between audit firms and their audit clients. ${ }^{83}$ Thirdly, from the aspect of administrative regulation it (vii)

${ }^{78}$ Section 301 of the act obliges all publicly registered companies to establish an audit committee which is directly responsible for the appointment, compensation and oversight of the work of the auditor, a public accounting firm registered by the new regulatory entity (PCAOB), employed by the issuer. This committee is composed of independent members and members of the board of directors. The other main part of this committee's work is to treat any complaints on accounting, internal controls and auditing matters. Lunt: op. cit. 252.

${ }^{79}$ Section 409 obliges each issuer to disclose to the public any relevant information regarding the financial situation of the company as rapidly as possible. Furthermore, according to section 401 every report containing financial statements, mainly the periodic reports, should reflect all "material correcting adjustments to [...] financial statements" which have been identified by an external audit firm. Lunt: op. cit. 254-255.

${ }^{80}$ Section 302 requires that both the principal executive and financial officer must certify in the quarterly and annual reports that they give a fair presentation of the financial situation, so to say the statements contained in the report are accurate and complete. Additionally, as required by section 906, these periodic reports submitted to the SEC have to include a certification prepared by the CEOs and CFOs that the given report fully complies with the relevant sections of the Securities Exchange Act. Lunt: op. cit. 251.

${ }^{81}$ Section 402 prohibits any credits in the form of personal loans to executive officers. Lunt: op. cit. 251.

${ }^{82}$ Section 806 forbids to discharge, suspend, threaten, harass or even discriminate against an employee because of the fact that this employee lawfully provided information or assisted in an investigation. If the employee can reasonably believe that a conduct constitutes a violation of any securities law he cannot be sanctioned due to her/his assistance to the public authorities. Lunt: op. cit. 255-256.

${ }^{83}$ Section 206 forbids audit firms to perform for a company any audit service if any of the companies' principal executive officers has been employed by the given audit firm and participated in any capacity in the audit of that company in the one year period preceding the actual audit process. Additionally, Section 201 explicitly prohibits auditors to provide eight specified non-audit services for the audit clients. Furthermore, section 203 requires that audit partners should rotate every five years. O'Neill, T.-Cardi, B.-Chabit, S.: Conflicts between French Law and Practice of the U.S. Sarbanes-Oxley Act of 2002. International Business Lawyer, April 2003, 62-63. 
strengthened the sanctions, both civil and criminal, for violations of securities law $^{84}$ and (viii) significantly broadened the prescriptive competences of the SEC over companies by delegating a general implementing power to it $^{85}$ and (ix) established a new administrative body, the Public Company Accounting Oversight Board (PCAOB) to register audit companies and set forth compulsory standards for the audit profession. ${ }^{86}$

\subsection{Arguments for justification and critics}

Obviously, the Sarbanes-Oxley Act has been a central topic of political, business and scholarly disputes since Congress passed it. In these debates one can distinguish an armada of arguments concerning the values and the disadvantages of the act. In the next part this paper shall try to summarize the most important lines of argumentation in order to indicate the worldwide reception of the act.

${ }^{84}$ If the principal officers falsely certify a report, or any report contains false statements, they have to face serious fines and/or prison sentences. In case of a "knowingly" false certification the penalty may be a fine up to $\$ 1$ million and/or prison sentence of up to 10 years. If it was committed "willfully" the penalties imposed are much more serious, a fine up to $\$ 5$ million and/or prison sentence of up to 20 years. Moreover, the act creates a new crime for the destruction, alteration or falsification of records in federal investigations and the destruction of corporate audit records in its section 802. Ibid.; Vancea: op. cit. 839. Footnote 32 .

${ }^{85}$ The act by its section 3 (a) gives a general mandate to the SEC to "promulgate such rules and regulations as may be necessary or appropriate in the public interest or for the protection of investors, and in furtherance of this Act." Until July 30, 2003 the SEC adopted 13 sets of rules in various areas, such as for example improving the independence of outsider auditors, requiring companies to disclose whether they have a code of ethics for the principal officers, or governing standards of conduct for attorneys practicing before the SEC. Section 1103 permits SEC to temporally freeze certain payments made to those who violated securities law, and due to section 1105 the SEC has an authority to prohibit persons from serving as principal officers or directors. For the details see http://www.sec. gov/news/press/2003-89a.htm; http://www.sec.gov/news/press/2003-89a.htm

${ }^{86}$ In order to enhance the transparency of the work of audit companies Section 101 created a new administrative body, the Public Company Accounting Oversight Board. One of the main areas of the work of this body is to register audit firms, because after the adoption of the act only publicly registered audit firms can provide audit services. Besides this authorization function it has the competence to adopt standards, as for instance auditing, quality control and ethics which should be respected by all registered companies. Moreover, this organ has a certain supervisory function because it can conduct inspections as well as investigations and disciplinary proceedings regarding public accounting firms, and it can even impose appropriate sanctions. Lunt: op. cit. 254. 


\subsubsection{Arguments of justification}

The main justification behind the Sarbanes-Oxley Act is the intention to defend the American capital markets and, in a broader sense, to protect the whole American free enterprise system. On the one hand President George W. Bush argued that this act provides "new tools" for the U.S. administration. ${ }^{87}$ And, these "new tools" make the American authorities able to defend the American free enterprise system against corruption and crime, even in an "aggressive" way. ${ }^{88}$ On the other hand, Senator Paul Sarbanes emphasized that the act is an essential piece of legislation in order to protect the investors' confidence in the U.S. corporate structures. Senator Sarbanes pointed out that the trust "in corporate executives and their financial reports" as well as the independence of accountants should be regarded as the main aims of the act. ${ }^{89}$ Consequently, the act is justified in the eye of the U.S. government by the aim of protecting the American system of capitalism through the defense of trust and confidence in the U.S. corporate structures. This governmental intent to restore the confidence can effectively contribute to the smooth functioning of U.S. capital markets, which can also be considered to be of vital importance to U.S. style capitalism.

Another argument for the justification of the act, on a scholarly level, is that it can potentially establish "global best practices", ${ }^{90}$ so to say it can foster the existing convergence of corporate models. ${ }^{91}$ Many experts state that the convergence of corporate governance models can lead to a substantial decrease of transaction costs of issuers and to an increased comparability of companies. Furthermore, it can also facilitate the opportunities of global firms to enter foreign public markets, and trade there with their shares. ${ }^{92}$ In conclusion, the convergence of corporate governance models based on worldwide recognized "global best practices" can reduce the transaction costs of the functioning of enterprises. And this reduction of transaction costs can increase the efficiency of world economy which may lead to a better performance of world markets.

\footnotetext{
${ }^{87}$ President George W. Bush's speech at the time of signing Sarbanes-Oxley, July 30, 2002. Quoted by Thompson: op. cit. 266.

${ }^{88}$ Ibid.

${ }^{89}$ Falencki: op. cit. 1214.

${ }^{90}$ Cohen, A.-Winter, M.: The Debate Sarbanes-Oxley. Accountancy Age, Sept 4, 2002. http://www.accountancyage.com/accountancyage/comment/2038648/debate-sarbanes-oxley

${ }^{91}$ Vancea: op. cit. 867-870.

${ }^{92} \mathrm{Cf}$. Ibid. 868. Footnote 169. At this point the author quotes the researches of John C. Coffee.
} 


\subsection{2. "Insider" and foreign criticisms}

The Sarbanes-Oxley Act has been under very severe criticism since its enactment in July 2002. Regarding these critics, one interesting, probably unusual point is that the act was criticized by U.S. issuers as well as foreign actors.

Smaller U.S. firms were quite vocal concerning the negative effects of the act on their businesses. Several advisory organizations came up with such conclusions that the burden created by the provisions of the act is quite significant for small companies being publicly listed. They also anticipated that for these small companies it is even advantageous to go private, that is to de-list from the stock exchanges, because they can avoid a considerable increase of their costs in this way. As for instance, a survey realized in 2004 found that for smaller companies, that is firms with annual revenues less than $\$ 1$ billion, the price to remain listed increased by 130 percent compared to the costs of the last pre-Sarbanes-Oxley year. ${ }^{93}$

Besides this increasing of compliance costs small firms can be threatened by a silent change in the attitude of audit firms invoked by the act. Due to the severity of the new rules regarding the auditors, audit companies, mostly the Big Four, may drop their clients considered to be too risky to work with them. Because of the fact that a Big Four audit is regarded by the business community as symbol of prosperity, losing this relation can send a bad message to possible investors. Furthermore, the increase in audit fees due to the act's audit provisions may also imply disadvantageous consequences for the smaller companies. ${ }^{94}$

The universal foreign criticism has basically been focused on the charge of illegitimate extraterritoriality of the act. ${ }^{95}$ Generally, the international community complained that the U.S. intended to act as a global regulator on the field of corporate governance practices, thus it did not respect, or even infringed the sovereignty of other countries to rule these activities. ${ }^{96}$ Consequently, the act appeared to conflict with classical principles of public international law on jurisdiction. Additionally, international business community raised a very clearcut point regarding the act's disadvantageous implications. In the view of foreign firms it has a very strong anti-competitive aspect vis-à-vis foreign companies. ${ }^{97}$ They argued that the cost of compliance for foreign companies is

\footnotetext{
${ }^{93}$ Stoltenberg-Lacey-George-Cuthbert: op. cit. 469. Footnote 72: first and second sections.

${ }^{94}$ Ibid. Footnote: 72 third section.

${ }^{95}$ Cf. Vagts, D. F.: Extraterritoriality and Corporate Governance Law. The American Journal of International Law 97 (2003) 293.

${ }^{96}$ Falencki: op. cit. 1218.

${ }^{97}$ Ibid.
} 
much higher ${ }^{98}$ errors, and therefore criminal penalties are much more likely, and some exceptions of the act favor U.S. companies. ${ }^{99}$ Additionally, the United Kingdom, Germany and Japan asserted that Congress failed to respect the principles of comity, which obliges the U.S. to adjust to those foreign regulations which are equivalent to the provisions of the act. ${ }^{100}$

The European Commission, either as a body or through its high officials, also indicated quite serious concerns about the act. In a communication of 2003 the EU Commission raised the problem of "outreach effects" on European companies as well as auditors and asserted that these can cause "a series of problems". ${ }^{101}$ Moreover, Alexander Schaub, Director General of DG Internal Market in his speech in the framework of an ECB Symposium criticized the act owing to the lack of consultation and the rather fast and hasty process in which it was enacted. ${ }^{102}$

Moreover, certain European companies explicitly declared that they have very serious doubts whether it is worthwhile to maintain their listing in New York. The increased costs of compliance to the new requirements may outweigh the benefits of being listed on the New York Stock Exchange. ${ }^{103}$ Moreover, almost two thirds of European CEOs said during a survey in 2003 that they are more reluctant concerning the access to U.S. capital markets then they have been prior to the Sarbanes-Oxley Act. These European CEOs argued that the over-regulation created by the act could be the biggest threat to the business. ${ }^{104}$ As an illustration of this wide-spread attitude among European

${ }^{98}$ Lunt: op. cit. 264. About compliance costs in details see: Thompson: op. cit. 265. Footnote 1. Concerning S\&P 500 companies the average costs of auditing fees in 2001 (the last prior-Sarbanes-Oxley year) was \$2.934.000, following the adoption of the act in 2002 it increased to an average of $\$ 4.048 .000$.

${ }^{99}$ Section 402 generally prohibits all loans to executives, but it provides certain exceptions for U.S. banks, on the basis that they are insured by a federal entity, the Federal Deposit Insurance Corporation. Falencki: op. cit. 1218.

${ }^{100}$ Ibid. 1211; for a detailed analysis of conflicting rules see Falencki: op. cit. 12251229.

${ }^{101}$ Communication from the Commission to the Council and the European Parliament, Modernising Company Law and Enhancing Corporate Governance in the EU-A Plan to Move Forward, COM (2003) 284, 2004 OJ (C 80) 12-16, quoted by Stoltenberg-LaceyGeorge-Cuthbert: op. cit. 468.

${ }^{102}$ Speech by Alexander Schaub, Director General of DG Internal Markets to the ECB Symposium, Money v. Ethics, Nov 29, 2002, quoted ibid.

${ }^{103}$ Ibid. 470.

${ }^{104}$ Schlesinger, L.: Sarbanes-Oxley scares off European CEOs. Accountancy Age, 24 Jan, 2003. http://www.accountancyage.com/accountancyage/news/2031960/sarbanesoxley-scares-european-ceos 
CEOs, Wendelin Wiedeking, Porches's CEO argued, when his company withdrew its plans for listing on the NYSE, that the certification requirement for CEOs and CFOs makes no sense, because German company law establishes a collective responsibility for the management board. ${ }^{105}$

\subsubsection{Scholarly problems}

The other part of criticism was raised by scholars and experts. A major part of this wave of criticism focused on the issue that the act is, in reality, an unambiguous exportation of U.S. corporate governance models. Some scholars even asserted that since the Sarbanes-Oxley Act was adopted without any foreign consultation, in a unilateral way, ${ }^{106}$ it can be a kind of American economic imperialism. ${ }^{107}$ Thus, from the aspect of international business environment including multinational companies as well as major powers of world trade, the act may indicate the intent of the U.S. to export its corporate governance model without taking into account other interests and divergent models.

From a more detailed perspective it can also be argued that the SarbanesOxley is not in conformity with those requirements which can justify its extraterritorial scope. According to an academic position neither the subjectmatter test nor the effects test can justify the extraterritoriality of the act. ${ }^{108}$ Due to the fact that that the act does not use any geographical terms and that the act's legislative history suggests that the act is mainly concerned with domestic problems, the Congress' intent to regulate extraterritorial affairs cannot be presumed. ${ }^{109}$ Additionally, since the act also tries to regulate that kind of conduct which cannot have substantial harmful effects on U.S. investors, because these conducts have already been effectively regulated by foreign legal systems, the act goes beyond those considerations which may justify extraterritoriality under the effects test. ${ }^{110}$ Additionally, it should also be taken into account that from the perspective of a comity analysis, even in the narrow sense of cases of true conflicts between U.S. and foreign laws, as accepted in the Hartford Fire ${ }^{111}$ judgment, the legitimate extraterritoriality of the act is highly questionable. ${ }^{112}$

105 Lunt: op. cit. 264.

${ }^{106}$ Stoltenberg-Lacey-George-Cuthbert: op. cit. 457; Vancea: op. cit. 874; Lunt: op. cit. 266.

${ }^{107}$ Falencki: op. cit. 1224.

${ }^{108}$ Vancea: op. cit. 849-860.

${ }^{109}$ Ibid. 853-854.

${ }^{110}$ Ibid. 858.

111509 U.S. 764 (1993).

${ }^{112}$ Vancea: op. cit. 861. 
Case-studies based on the post-Sarbanes-Oxley experiences revealed the fact that certain provisions of the act conflict with some structural elements of U.S. or foreign legal systems. Section 307, for instance, requires an attorney representing an issuer to report any evidence of a material violation of securities law to the chief legal officer or to higher forums, as the Audit Committee or the Board of Directors. This provision obviously conflicts with the American Bar Association's model rules of professional conduct which require the attorney not to disclose any information without her/his client's permission. The narrow exceptions provided by these model rules, preventing the client from committing a criminal act which likely result in imminent death or substantial bodily harm, can obviously not be applied to this case. ${ }^{113}$

Some whistleblower protection provisions can also be in conflict with national legal systems. In order to get all relevant information related to the work of the whole company; companies should establish anonymous tip-lines through which an employee can inform the management of the company without giving any personal information. ${ }^{114}$ However, these tip-lines are not in conformity with the data-protection rules applied in the EU. In France in the case of McDonalds the French Data Protection Authority found that McDonalds by introducing an anonymous tip line failed to comply with the French Data Protection provision, hence it did not authorize this tip-line system. ${ }^{115}$ A German Court also established that a similar tip-line created by the Wal-Mart Group is contrary to the provisions of the German Works Constitution Act. ${ }^{116}$

\subsection{General Assessment}

The most general and most important effect of the Sarbanes-Oxley Act is the significantly stronger U.S. governmental position in the supervision of financial markets and their operations. ${ }^{117}$ The act established a new administrative body, the Public Company Accounting Oversight Board, and broadened the competences of SEC by mandating it with the implementation of the act. So, one can easily recognize a shift in the attitude of the U.S. legislator. By this act the legislator abandoned the former regulation model based on the self-

113 Thompson: op. cit. 268.

114 Ibid. 269-270.

115 Ibid. 271-274.

${ }^{116}$ Ibid. 274-277.

${ }^{117}$ Ehrat, F. R.: Sarbanes-Oxley-a View from Outside. International Business Lawyer, April 2003. 77. 
regulation mechanisms established and managed by market-participants, and proceeded to a novel model in which state supervision has the preeminent role. ${ }^{118}$ It may also indicate that the U.S. legislator recognized the relevance of the enhanced governmental regulation of financial markets in order to tame those turbulences which might be caused by the market actors' conduct.

Taking into account the importance of U.S. capital markets on the world scene it seems to be quite likely that the act shall have a certain benchmark effect. ${ }^{119}$ Foreign legislators may regard the Sarbanes-Oxley Act as a reference point or a model having certain provisions which might be worthwhile to take into consideration during the drafting of new corporate governance standards. For instance, during the discussion of $8^{\text {th }}$ Company Law Directive on statutory audit Commissioner McCreevy suggested very similar points on the further development of EC law in this area. ${ }^{120}$ Inter alia he emphasized that the directive should clarify the duties of auditors, their independence and their ethics. Moreover he argued for a "robust public oversight of the audit profession". ${ }^{121}$

The recent version of this directive being in force obliges public-interest entities to establish an audit committee which should primarily monitor the financial reporting process and the effectiveness of the company internal audit and risk management system. ${ }^{122}$ It is not too difficult to identify the same underlying philosophy behind the above-cited article of the EC directive and the relevant paragraphs of Sarbanes Oxley Act on audit committees. Both the U.S. and the EC legislator attempts to strengthen the independence of audit mechanisms by establishing a new committee within the traditional corporate structures in order to minimize the risks arising from the possible interlocking of companies and audit firms.

In conclusion, the Sarbanes-Oxley Act does not only profoundly changed the regulative framework of U.S. financial markets by setting forth new standards for publicly listed companies, but revealed a new tendency of U.S. legislation which proceeds to an increased governmental intervention in former self-regulatory areas. Additionally, the act can also illustrate another change in the U.S. legislator's approach concerning extraterritoriality; instead of the

118 Ibid.

119 Ibid.

${ }^{120}$ Naturally, the effects of Parmalat collapse in 2003 should also taken into account as a significant motivation to adopt an ammended version of the former directives on audit controls. Cf. Stoltenberg-Lacey-George-Cuthberg: op. cit. 478-481.

${ }^{121}$ Ibid. 482.

${ }^{122}$ Directive 2006/43/EC of the European Parliament and of the Council of 17 May 2006, Art 41. 
former international practice focusing on the search for cooperative solutions to extraterritorial problems, the U.S. legislator privileges the unilateral solution nowadays.

\section{Sovereignty in the mirror of the recent extraterritorial developments}

\section{Introductory remarks}

Sovereignty is one of the most important basic antinomies in the understanding of modern international law. Its precise meaning, boundaries and relevance has been broadly debated in our age, however these very intense scholarly disputes indicate its inestimable importance within the structure of international law. ${ }^{123}$ Extensive debates on sovereignty, from the most different perspectives, are quite frequent, but a theory of international law without sovereignty, at least as an antithesis, is nearly unimaginable. Hence, it is a rational solution to compare the earlier findings with certain dimensions of sovereignty, since it may facilitate to better understand both our findings and sovereignty in itself. $^{124}$

In the next part the paper will reflect the earlier findings to the concept of sovereignty by using three different prisms. Each prism-Legislatio, Legitimatio and Subordinatio-will highlight a peculiar feature of sovereignty to compare this feature to recent extraterritorial developments. This method may make possible to better comprehend the effects of Sarbanes-Oxley Act on the general concept of sovereignty and formulate some conclusions.

\section{Legislatio-sovereignty as legislation}

Those international lawyers who rely on the heritage of Jean Bodin agree that legislation is the most crucial aspects of sovereignty. ${ }^{125}$ By the 'invention' of sovereignty Bodin created the modern state's most relevant conceptual basis.

${ }^{123}$ Cf. Jennings, Sir R.: Sovereignty and International Law. In: Kreijen, G. (ed.): State, Sovereignty and International Governance. Oxford, 2002. 27.

${ }^{124}$ Due to the differences in the interpretation of this concept, this paper does not endeavor to work out a comprehensive definition. In the following analysis it will only apply certain dimensions of sovereignty, which should be a part of it, however they should not be every part.

${ }^{125}$ Cf. Jennings: op. cit. 30-31. Sir Jennings here argues that these years' tragic situations related to 'failed states' in Asia and Africa are obvious symptoms of the decline of state sovereignty. 
If the modern state is sovereign all governmental functions, so to say the corollaries of statehood like legislation, execution and judiciary, are easily explainable coherently from the point of view of public law. Since every state competence emanates from a final axiom, from the suprema potestas. And one particularly relevant dimensions of sovereignty is legislation, as Bodin formulated it: an essential manifestation of sovereignty is the power to make the law. ${ }^{126}$ Or, in a more modern wording: a state's sovereign right to regulate ${ }^{127}$ those conducts which are under its jurisdiction, if certain requirements regarding the basis for it are met.

The Sarbanes-Oxley Act is a sovereign legislative act in an age when most scholars talk about the disappearance or the erosion of traditional sovereignty presuming a governmental center of decision-making. ${ }^{128}$ They argue mostly following these three patterns. First, in our world classical state sovereignty is diminishing since the interlocked nature of world economy and its economic self-regulation regimes make it meaningless. ${ }^{129}$ Hence state sovereignty is a possible source of binding norms, but neither the only one, nor a privileged one. Secondly, besides the classic governmental level alternative, that is from sub-national units to supra-national or global processes, decision-making centers have been emerging since the end of Cold War. ${ }^{130}$ Therefore, more and more parts of decisions are made on a level, or in a process which is not the traditional governmental one. And thirdly, due to the considerable improvement of regulatory elements in international law, such as for instance human rights enforcement mechanisms, international law erodes governments' sovereignty

\footnotetext{
126 "Primum ac praecipium caput majestatis [...] legem universis ac singulis civibus dare posse" quoted by Ibid. 27.

${ }^{127}$ A. W. Lowe argues that economic sovereignty, as a theoretical concept, may help in deciding jurisdictional conflicts by summarizing those points-a central core of economic rights-which can justify the extraterritorial reach of a given act. Cf. Lowe, A. W.: The Problems of Extraterritorial Jurisdiction: Economic Sovereignty and the Search for a Solution. The International and Comparative Law Quarterly 34 (1985) 744-746.

${ }^{128}$ For a comprehensive overview from the point of view of international relations see: Jennings: op. cit. 33-35.

${ }^{129}$ Cf. Teubner, G.: Global Bukowina: Legal Pluralism in the World Society. In: Teubner, G. (ed.): Global Law Without a State. Aldershot-Brookfield USA-SingaporeSydney, 1997. 4-7.

${ }^{130}$ Cf. Brühl, T.-Rittberger, V.: From International to Global Governance: Actors, Collective Decision-Making, and the United Nations in the World of Twenty-first Century. In: Rittberger, V. (ed.): Global Governance and the United Nations System. Tokyo, 2002. 1-6.
} 
to comprehensively regulate domestic affairs. ${ }^{131}$ That being said, governments should incorporate norms having an international or supranational law origin into their legal systems without possessing any discretion for their implementation.

Notwithstanding this, the Sarbanes-Oxley Act suggests a slightly differentiated conclusion about the imaginable future of sovereignty. Through classical lenses this act is the best example of a traditional sovereign legislative act. When Congress passed the act, it made a serious effort to change the whole framework of such a regulatory area-law of securities and corporate governance-which has a strategic importance from the perspective of the whole U.S. economy in the age of globalization. Thus, this 'draconian' change in the law of securities is in the very national interest of the U.S. In doing so, the legislator was quite reluctant to take into account the legitimate interests of other states or those of the international community, in one word comity concerns. So, the act had been passed in a unilateral way, which was shocking as a new state practice regarding the cooperative solution of extraterritorial issues seemed to be gradually emerging at the end of the 90 's. ${ }^{132}$ But, the U.S. legislator simply disregarded this former practice and enacted the act without any serious doubts in its legality concerning all international law aspects. Furthermore, the SEC, being responsible for its implementation, has also been very reluctant to consider foreign complaints, although it provided some extension of compliance deadlines, it did not permit any exemptions from the scope of the act for foreign companies. ${ }^{133}$

In conclusion, the example of the Sarbanes-Oxley Act unambiguously shows that notwithstanding all those considerations and achievements which may suggest the rethinking of the classic theories of public international law largely

${ }^{131}$ Cf. Weiler, J. H. H.: The Geology of International Law-Governance, Democracy and Legitimacy. Zeitschrift für ausländisches öffentliches Recht und Völkerrecht 64 (2004) 559.

${ }^{132}$ All examples of this emerging practice in antitrust cases-Agreement relating to Mutual Co-operation regarding Restrictive Business Practices of 1976 (USA-Germany), Agreement relating to Co-operation on Antitrust Matters of 1982 (USA-Australia), the final outcome of the Boeing and McDonnell Douglas merger, and the Transatlantic Partnership on Political Cooperation and Understanding with Respect to Disciplines for Strengthening of Investment Protection in 1998 about the effects of the Helms-Burton and D'Amato Acts between the United States and the European Union-showed that the parties concerned can find cooperative solutions.

${ }^{133}$ This is contrary to the former SEC practice, which exempted foreign companies from certain obligations flowing from the securities acts. For a more detailed discussion see Falencki: op. cit. 1229-1231. and Lunt: op. cit. 250. 
based on sovereignty, sovereignty as a right to legislation is still in force and can be a powerful tool in the hands of governments. And, governments by using this tool can seriously disturb the recent structure of international law by creating such a situation which is obviously contrary to the universally recognized principles of international law. However, this attitude is such a reality which renders the adjustment of both international and national policies necessary.

\section{Legitimatio-sovereignty as a value-basis in the construction of international law}

From the second half of the $19^{\text {th }}$ century to the first decade of the $20^{\text {th }}$ century, transactionalism was the dominant assumption in the theory of international law. This approach was mostly based on such interlinking concepts as sovereign equality, consent and pacta sunt servanda. ${ }^{134}$ It also meant that the basic legitimating source of the whole international order based on an international law mostly comprised of bilateral treaties was the sovereign will of actors. So, behind the whole system of international law stood the states' sovereign will as a fundamental cornerstone of the entire world order. Therefore, from this perspective, Sovereignty, that is to say sovereign equality, could be regarded as the preeminent legitimating source of international law.

However, following the end of World War I and owing to the hard lessons stemming from it the value structure of the international system has begun to gradually change. First of all, Stability as a value has appeared. It primarily meant that the maintenance of the stability of the international system with the help of a multilateral framework should be considered as a value of humankind. This conviction was reflected among the objectives of the League of Nations in an embryonic form, ${ }^{135}$ and considerably elaborated in the UN Charter. ${ }^{136}$ Then, Human Rights have also become a legitimating factor of international law as they were concretized in the UN human rights system, from a solemn declaration through covenants to implementing and follow-up mechanisms. ${ }^{137}$ Moreover, international Rule-of-Law, meaning the slow formation of increasingly

${ }^{134}$ Cf. Weiler: op. cit. 555.

${ }^{135}$ Preamble, Art 8 first para, Art 10, Art 11. The Covenant of the League of Nations.

${ }^{136}$ Art 1. UN Charter.

137 de Wet, E.: The International Constitutional Order. International and Comparative Law Quarterly 55 (2006) 58. 
refined and complex international dispute settlements systems, ${ }^{138}$ also got quite an important place within the values of the international community.

Thus, the value-basis of international law is much richer and broader today than it was at the turn of the $20^{\text {th }}$ century, when Sovereignty had a predominant place in this construction. Therefore, legitimization of international law emanates from these values which can even permit the restriction of Sovereignty in order to favor other values.

The legislative attitude behind the Sarbanes-Oxley Act is exclusively based on the sovereignty of Congress. Within certain constitutional limits ${ }^{139}$ Congress can regulate anything, even conducts occurring outside the territory of the U.S., and it is only legitimated by Sovereignty. It is not too difficult to recognize that this approach has clearly originated from that century when Sovereignty, and the national interest implied within it, was the predominant legitimating factor in international law. So, as the example of the Sarbanes-Oxley Act shows it, this classic attitude did not at all disappear under the influence of the new values, it can again-and-again appear if a certain constellation of facts invokes it.

What could be the major factors being able to trigger this attitude? On the basis of lessons arising from the Sarbanes-Oxley Act one of them is clearly identifiable. If basic or vital interests of a state are at stake, it is quite likely that the given government will answer by bringing out the mask of Sovereignty. And, if this state has enough power, ${ }^{140}$ in military, economic and diplomatic sense, to disregard or neglect the reactions of the international community, such an answer will be even more likely.

4. Subordinatio-sovereignty with the eyes of subjects

${ }^{138}$ For a comprehensive overview of the web of international, regional and specialized tribunals as well as international administrative tribunals and international arbitral tribunals see: Burgenthal, T.: Proliferation of International Courts and Tribunals: Is it Good or Bad. Leiden Journal of International Law 14 (2001) 267-271.

${ }^{139}$ Concerning extraterritoriality the Congress is limited by the so-called "subjectmatter" test which comprised of two mutually interlinked assumptions. The first one is the "Charming Betsy presumption" implying that legislative acts cannot to be enacted in violation of international law. The second one, the Foley Bros. presumption, asserts that an act of Congress, unless a contrary intent appears, can be applied within U.S. territorial jurisdiction. The intent of Congress, if it is not an explicit one, can be revealed from the given act's legislative history and the related administrative decisions. This doctrine was revitalized by the Aramco judgment in 1991. Cf. Vancea: op. cit. 849-852.

${ }^{140}$ Cf. Rynagaert, C.: The Limits of Substantive International Economic Law: In Support of Reasonable Extraterritorial Jurisdiction. KULeuven Institute for International Law Working Papers, No. 99, Aug. 2006. at http://law.kuleuven.be/iir/nl/wp/WP/ WP99e.pdf, $2.4^{\text {th }}$ para. and $5.3^{\text {rd }}$ para. 
From a different angle, sovereignty necessarily implies the fact of subordination to the suprema potestas. All subjects under the scope of the sovereign must obey to its acts so long as the conditions for a legitimate practice of sovereign powers are satisfied. In modern international law this conviction is reflected in the very refined doctrine of jurisdiction as well as in the detailed rules of conflicts-of-laws. Thus, doctrine of jurisdiction and conflict-of-laws rules orientate that fundamental preparatory process in international law whereby a person is subjected to a given legal system which emanates from the will of a sovereign. Therefore, these areas of law, which may have a marginal significance compared to the weight of substantive provisions, have a vital importance regarding the element of subordinatio in international law. So, state practice concerning the extraterritorial reach of a sovereign act can have fundamental importance from the point of view of potential subjects.

In accordance with the provisions of the act every issuer is under the scope of the Sarbanes-Oxley Act if its securities are registered on the U.S. financial markets or it has to report regularly to the SEC. In order to get a slightly more precise picture on the relevance of this section it is worthwhile comparing the list of top 200 transnational companies with the list of registered companies on the U.S. securities exchanges. ${ }^{141}$ In 1999 , so during the pre-Sarbanes-Oxley period, from the top 30 transnational companies 21 companies were foreign in accordance with their place of incorporation and the remaining 9 were incorporated in the USA. From the foreign multinational companies only 7 companies were not registered under the SEC (4 Japanese and 3 German multinationals). This fact means that the most powerful players of world economy attach a substantial importance, due to a number of reasons as for instance access to nearly unlimited sources of capital or indicating the prosperity by being registered on such prestigious marketplaces, to the fact of being registered on U.S. capital markets. So, a considerable majority of top global multinational companies $^{142}$ is an actor on the U.S. securities markets, that is to say they have to act under the scope of U.S. securities law even if they are de facto foreign companies. Nevertheless, until the birth of the Sarbanes-Oxley Act the SEC

${ }^{141}$ Cf. S. Anderson and J. Cavanagh: Top 200-The Rise of Corporate Global Power. at http://www.ips-dc.org/downloads/Top_200.pdf 10. Table 3. Top 200 (1999); and International Registered and Reporting Companies, Alphabethical Listing (2000) at http://www.sec.gov/divisions/corpfin/internatl/alpha2000.htm

${ }^{142}$ About multinational or transnational companies in general see: Wallace: op. cit. 913 and $60-70$. 
provided them some exception from those obligations which must be completely fulfilled by domestic companies.

With the passing of the Sarbanes-Oxley Act Congress in fact tried to fully subject all registered companies to its jurisdiction notwithstanding their place of origin or registration. So, the U.S. Sovereign sent a clear message to the major actors of the global economy: if they want to have access to the U.S. capital market they have to fully comply with the requirements of the act, even if this extraterritorial reach is contrary to international law and the former international practice, or the compliance costs are too high. Foreign multinationals can only stay on the domestic capital markets if they accept these new rules emanating from the will of sovereign. In any other case, due to whatever legitimate reason of non-compliance, transnational companies must leave the U.S. securities exchanges because exemption from the scope of the act is impossible.

In conclusion, if transnational companies would like to participate in the exploitation of U.S. capital sources, they have to subject their full corporate governance system to the new rules created by the Sovereign. So, Congress offered them a stay or leave solution via neglecting the classical mechanisms to deal with the problem of subordinatio developed by scholars and state practice in the last century. This attitude revealed again, in a very bluntly way, the element of subordinatio in sovereignty which was successfully disguised and tamed by the doctrine of jurisdiction and international private law.

\section{Final comments}

The comparison of the Sarbanes-Oxley Act to these three profoundly interlocked dimensions of sovereignty-Legislatio, Legitimatio and Subordinatio-can lead us toward a slightly non-conventional conclusion. First of all, it should be recognized that the whole concept of sovereignty is under transformation. The concept of sovereignty is changing since states are more-and-more willing to give up or confer certain competences to international organizations. Moreover, the international, perhaps it is better-to-say global context of international law has also considerably changed, and this transformation also eroded some original aspects of sovereignty mostly in an economic sense.

However, as the case of the Sarbanes-Oxley Act unambiguously shows, this does not at all mean that sovereignty is completely disappearing, rather that its function has been transforming to a certain degree. Nowadays, in accordance with the emblematic example of the Sarbanes-Oxley Act, legislative sovereignty-legitimated by the sovereign interest and the goal of subjecting certain actors to the sovereign regulative competences in order to protect vital 
national interests-might be conceived of as an ultima ratio, a last legal basis which can be very efficiently invoked.

In conclusion, it is quite plausible to say that the classical $19^{\text {th }}$ century approach of sovereignty is outdated, but sovereignty is still in play if the question is the protection of fundamental national interests. One may formulate this conclusion from a different angle, too: under the layers of global interdependence, multilateralism, regionalism and international regulatory processesthat is to say under the surface of those factors of which our age's international environment is comprised-we can get to see Sovereignty if a certain constellation of facts invoke its re-appearance. And, it has exactly happened in the case of the Sarbanes-Oxley Act. 